\title{
Types of Strategies in English Online Learning to Inclusive Students
}

\author{
Arjuna Peranginangin ${ }^{1, *}$ Rahmad Husein ${ }^{2}$ Sumarsih $^{3}$ \\ ${ }^{1}$ English applied Linguistic, Universitas Negeri Medan, Medan, Indonesia \\ ${ }^{2}$ English applied Linguistic, Universitas Negeri Medan, Medan, Indonesia \\ ${ }^{3}$ English applied Linguistic, Universitas Negeri Medan, Medan, Indonesia \\ *Corresponding author. Email: anginarjuna78@gmail.com
}

\begin{abstract}
This study deals with types of learning strategies of English online learning to inclusive students at SMAN 2 Lubuk pakam. the study was conducted to identify types of learning strategies. This research is a descriptive qualitative research. To obtain the data, 7inclusive students, 3 regular students and 2 English teachers were observed and interviewed. In doing the analysis, Miles, Huberman and Saldana (2014steps theories were used. To achieve the objective, the steps used were data condensation, data display and data verification. The result shows that there are four strategies found namely: independent teaching strategy $(32.5 \%)$ indirect instruction strategy (23.5\%), emperical/experient learning strategy (25\%), and interactive teaching strategy (19\%).
\end{abstract}

Keywords: component, formatting, style, styling, types of learning strategies, online, learning, inclusive students.

\section{INTRODUCTION}

Studies of learning strategies have been wide in area of applied linguistics. And It is good for the progress of developing and creating new strategies and approaches of learning language. Next the subject of learning strategies have been studied by numbers of experts: e.g. Rubin (1975), Tar one (1980), stern (1983), and Oxford (1990), pointed that Basically learning is process of change of attitude and action as result of experience and exercises. While learning strategies is as "operation employed by the learner to aid the acquisition, storage, retrieval and use of information. they are specific actions taken by the learner and teacher to make learning easier, faster, more enjoyable, more transferable to new situation: Stern's (1975 and 1983). The objective of learning is the change of behavior's which covers knowledge, skill and also attitude of personal or communities:" Djamarah and Zain (2010).

Next, OECD (2005) pointed online learning as a use of technology and information in different educational levels to improve and encourage learning in higher education institutions and includes the use of information and communication technology as a complement to the traditional classroom, online learning or mixing the two modes. In other words, online learning does not limit by time, place, and distance.

While, from the regulation view, Education consist of formal and Informal. With other words formal education usually done in the class room based and provided trainer, while informal education is one that is not structured and can be acquired at home or through apprenticeship. Special schools also exist consisted of regular ones for learners with one form of challenge/impairment or the other (Special needs learners) This category of learners include the hearing impaired; visual impaired, learning disabled, physical and health impaired, the gifted and talented; mild mental retardation, pastorals and nomads, etc. Experience in the past had shown that this category of learners were usually managed and educated in special schools; specifically meant for people with various disabilities; while regular learner (learners without disabilities) were and are still usually educated in normal or conventional schools. In recent years however, and especially in the wake of the Salamanca Declaration of 1994, the idea of establishing inclusive schools has been projected the world over. Inclusive education is that type of Education in which regular (normal) and special needs learners are brought together in the same academic environment and 
classroom for the purpose of learning. The adoption of this system of education could be in realization of the importance of the Universal Declaration of Human Right (United Nations, 1948) which stipulated that education is a fundamental human right. The Convention on the Rights of the Child (United Nations, 1989) also declared that children with or without disabilities have the same right to educational opportunities.

This new understanding to education (inclusion) came with some challenges which influence the school authorities and teachers trainer to manage that meaningful and intentional engagement of regular and students with special needs is done in a way that provides learning opportunities/activities and ensures that the environment is conducive to all students. Weiner (2003) is of the view that the teachers' moral obligation to be committed to expecting all students meet high standard of achievement and to provide an excellent learning environment is paramount in inclusive should also ensure equal participation of all learners in a differentiated curriculum, and intra-curricula activities. Implementation of instructional strategies and methods that increase regular and special needs students Participation and progress in the differentiated curriculum is very essential for success in an inclusive setting. Special needs students who are included in regular education classrooms are expected to be active participants in classroom instruction and to be challenged academically at the same level with the regular students. It is obvious that in inclusive classrooms, students learn in different ways. This is a challenge to teachers with diverse group of learners (MacLean, 2001). Ayres and Hedeen (1996) recognized that teaching the specialneeds child requires ateam approach with pre-determined common goals. However, Mostert (1996) found that although the theory is that administrators and teachers will collaborate with parents and students, the reality is that these expectations are too high given time constraints.

\section{LITERATURE REVIEW}

Strategies are the usage to win the war, include quality and quantity of tools, energy and other resources to support the military system.

Although it comes from an earlier military definition, in line with a plan of action of a general (Harper, 2016 and Oxford, 1990). The meaning of strategy as a plan of action toward a goal is widely accepted in other sectors; such as in economy, education, political system and so on. Then the innovative definition of the word learning has two complementary parts: (a) "finding or following the track" (based on ancient Proto-Indo-European roots cited by Harper, 2016, which suggests ongoing movement in a desirable path; and (b) the development of "knowledge or skills through experience, study, or by being taught" (from the Oxford Dictionaries, 2016), thus via informal or formal means.
Putting these aspects of strategy and learning together, we have an important definition: learning a strategy is the learner's plan of action for finding or following the desired track through experience, study, or by being taught." This core definition of learning strategies than be explored by a numbers of experts to have wider senses of learning strategies. As the result from 1975 to 2017, there are 33 definition of learning strategies. The following some of definitions of learning strategies and language learning strategies from experts:

First, Rubin (1975) stated learning strategies is the techniques or devices which a learner may use to acquire knowledge, so this definition focuses on the use of devices and technical of learner to achieve learning objectives. E.g.: the use of smart phone or laptop to access learning activities, or during the learning process the learner may have discussion, listening to audio or watching video are also included to learning strategies. So his statement considers learning strategies from the learner requirement of learning.

While Ellis (1994) define Learning strategies: "general tendencies or overall characteristics of the approach employed by the language learner, leaving techniques to refer to particular forms of observable learning behavior" e.g.: how serious a student to follow the learning process, does he give his or her time or just attending to learning process as the form of administration requirement. This definition sees strategies in the aspect of behavior and learner characteristic to observe learning activities.

Hamruni (2009, explains there are five types of online learning strategies. He pointed that there are five types of online learning strategies namely: Direct instruction strategy, indirect instruction strategy, experiential/ emperical learning strategy, interactive teaching sterategy and independent teaching strategy.

\subsection{Direct Instruction learning strategy}

Hamruni (2009), points that Direct instruction teaching strategy is teaching directed by the teacher directly. This strategy is effective to determine information or to build a skill step by steps. The direct instruction usually has deductive character. The superiority of Direct Instruction Teaching Strategy is this strategy so easy to be planned and used, while the core important weakness in the developing ability, the process and the attitude that needed in critical idea and interpersonal relation also learn.

\subsection{Indirect Instruction teaching strategy}

Hamruni (2009), next states that Indirect instruction teaching strategy often referred as inquiry, inductive, problem solving, decision making and invention. Contrary to direct instruction teaching strategies, indirect instruction teaching strategies put students as centers, even though both of them can complement each other. In 
this strategy the role of the teacher moves from the speaker to the facilitator. The teacher manage learning environment and give the students an opportunity to involve in the environment. The advantages of indirect instruction teaching strategies are:

A) Pushing interest and curiosity of the students

B) Creating the alternative and solving the problem

C) Pushing creativity and developing interpersonal skill and the other ability

D) Better understanding

E) Expressing understanding

This strategy takes a long time, and the results are difficult to predict. This strategy in not appropriate if students need a memory quickly.

\subsection{Interactive learning strategy}

The other types of online learning strategy based on Hamruni (2009) is Interactive learning strategy emphasizes on discussion and share between the learners. It will encourage of learner to create new an idea or concept, reacting on experiences, approach and developing alternative mindset. The superiorities of interactive teaching strategy are students can improve their social skill and their ability, developing of rational argument. The weaknesses of this strategy is depend on the creativity of teacher to arrange and develop the group dynamics

\subsection{Experiential/ empirical teaching strategy}

Empirical teaching strategies according to Hamruni (2009), have orientation in inductive activities. In this case students as the center. Self-reflection about their experience, is a planning formulation to achieve implementation based on context. The advantages of this strategy are able to increase student participation, as well as increase in student analytic aspects. While the disadvantages of this strategy are a high cost, and takes a long time.

\subsection{Independent teaching strategy}

The last types of online learning strategy pointed by Hamruni (2009) is Independent teaching strategy. The purposes of independent teaching strategy are developing of individual initiative, able to develop themselves and students must be active in learning. The advantage of this strategy is create student respect, while the disadvantage is that implementation is difficult for young students.

\section{RESEARCH METHOD}

This research was conducted by applying a qualitative descriptive research design. Bogdan and Biklen (1992) pointed that qualitative research is conducted through intense and/or prolonged contact with participants in a naturalistic setting to investigate the everyday and/or exceptional lives of individuals, groups, societies, and organizations naturalistic design was when the research main focus to observe person or persons in their natural state a undisturbed. Firstly, before doing the study, the researcher should find the issue and the problem of that issue that will be analyzed. The researcher should have a specific reason to do that research. This study aimed to get an understanding of the case that uses the theory of the previous researcher. Cohen (2017) argues that Content analysis is related to the summarizing and reporting written data in the research form. It means that the result of the data should in written form even though the sources from the video, interview, the recording, or others that not in written form.

\subsection{Data and data sources}

Bogdan (1992) states the data collected in the term of non-statistic, which is rich in description of people, places, and conversations, and not easily handled by statistical procedures. The data of the study were the sentences that stated by English teachers and inclusive students during interview and observation were conducted. next, it was transcribed in to written text. While the source of data in this study was consisting of 10 inclusive students and 2 English teachers at SMA N2 Lubuk pakam. The method of taking those 2 English teacher and 10 inclusive students as the participants in this research is with purposive sampling technique (sampling with destination). Purposive sampling according to Sugiyono (2009: 85 ) is sampling technique with certain considerations. In this study, the participants were consisting of 2 English teacher and 10 inclusive students. Participants are people in the research setting who are used to provide information about the situation and research background conditions. Utilization of informants for research is so that in a relatively short time a lot of information can be really affordable (Basrowi and Suwandi, 2008: 86). Another part of the informant is as a feedback provider to research in order to cross check the data (Bungin, 2011: 133

Data collection is the method or way to collect the data in this research. Marshal (2006) argues that data collection relies on four methods: 1) participating in the setting, 2) observing directly, 3) interviewing in depth, and 4) analyzing documents and material culture. The techniques of collecting data for this study were the data were two techniques of collecting data that were applied in this research, they were observation and interview. To get empirical evidence, the researcher did participant observation and interview.

Next the technique of data analyses, the writer use the theory of Miles, Huberman \& Saldana's Interactive Model (2014). this theory analyses the data in three steps: data condensation, data display and drawing conclusion. 


\section{RESULT AND DISCUSSION}

As Hamruni ((2009), proposed learning strategies in five types. They are direct instruction learning strategy (direct I.L.S), indirect instruction learning strategy (indirect I.L.S), interactive teaching strategy interactive.T.S), Experiential/ empirical learning strategy (Experiential/ empirical.L.S), and independent teaching strategy(independent .T.S).

The following on the Table 4.1 below show the types and percentage of each learning strategies

Table 4.1. Types of learning strategies

\begin{tabular}{|l|l|l|l|l|}
\hline No & Types & $\begin{array}{l}\text { Grade } \\
\text { XI }\end{array}$ & $\begin{array}{l}\text { Grade } \\
\text { XII }\end{array}$ & $\begin{array}{l}\text { Percentage } \\
(\%)\end{array}$ \\
\hline 1 & Independent T.S. & 30 & 35 & 32.5 \\
\hline 2 & Indirect I.T.S. & 27 & 20 & 23.5 \\
\hline 3 & Direct I.TS & 0 & 0 & 0 \\
\hline 4 & Empiricall.S. & 26 & 24 & 25 \\
\hline 5 & Interactive T.S & 17 & 21 & 19 \\
\hline \multicolumn{2}{r|}{ Total } & 100 & 100 & 100 \\
\hline
\end{tabular}

From table 4.1 above, showed the types of english online learning strategies used at SMA N2 Lubuk Pakam grade XI and Xii. There were four types of learning strategies used in grade XI and another finding, the most dominant type in learning strategy is independent instruction teaching strategy, and the lowest frequency is interactive teaching strategy. In grade XII there were also four learning strategies used, and another finding, the most dominant is independent instruction learning strategy and the lowest is Indirect instruction teaching strategy. While Direct instruction teaching strategy were not use both in grade XI and grade XII. Because both teachers and students of English online learning for inclusive students in grade XI and grade XII did not established meeting by video or virtually. They just use Whatsapp group and google classroom. E.g. The teachers just conducting the online lesson by sending tasks on Whatsapp groups. And in completing the tasks every student did their task with internet help.

Indirect instruction teaching strategy was held in the form of using electronic and communication tools to attach between students and teachers in doing their english lesson every week. E.G when an English teacher delivered the lesson the teacher just sending the material based on the schedule than the students have to check the lessons based on the schedule provided. It was often no oral communication among teachers and students during some meetings. The measurement was the only the sign of the students attendance in the learning management systems. Empirical learning strategies was used both by students in the form of applying devices such as using smart phone, laptop to connect with online lesson. E.g the teacher presented the teaching activities by sending voice note on Whatsapp group, google classroom or google meet. Then the students must be familiar with those applications to enable them to follow the class.
But direct instruction strategy was not found during the online lesson.

\subsection{Independent on Teaching Strategy}

The purposes of independent on teaching strategy are developing of individual initiative, able to develop themselves and students must be active in learning. The advantage of this strategy is create student respect toward their subject which were they focus on. However, empirically, based on the observation activities, every student must contain independent learning strategy during receiving English online learning.

The students have very limited time and opportunity to meet their teachers. Most of class meeting organized the assignment activities. To complete the assignment their struggle's and creativity toward particular subject might growing up. Every students manages themselves to find proper learning strategy to face online learning. So those were called independent learning strategy.

Question: $\mathrm{R}=$ researcher and $\mathrm{S}=$ student

R: Seberapa banyak kamu belajar secara mandiri saat menyelesaikan tugas-tugas pembelajaran secara online?

How much did you learn independently when finishing your online English assignment?

S: Sangat banyak pak, sebagian besar jawaban justru saya cari dari internet atau youtube secara mandiri

Very much sir, I actually looked for most of the materials from the internet or youtube independently

From the Answer above showed that the student did the english learning most by other sources such as Youtube, google and other internet providers, it means the students did not directly learn from the teachers.

The following statement below was the answer toward the interview with another inclusive student in grade XI

R: Seberapa banyak kamu belajar secara mandiri untuk dapat tetap menyelesaikan tugas-tugas pembelajaran secara online?

How much did you learn independently to make you exist in finishing your online English assignment?

S: $\quad$ sesungguhnya selama belajar online saya justru kebanyakan belajar secara mandiri.

"actually, during following English online learning, I learn so much independently."

From the expression above showed that in joining English online learning both in grade XI and XII, they used internet services such as Youtube, Google and other 
services. From the observation data also found that most learning activities were done in the form of distributing materrials by Whatsapp and google classroom.

\subsubsection{Indirect Learning Strategy}

The next other learning strategy was indirect learning strategy. As Hamruni (2009), describe indirect strategy as Indirect instruction teaching strategy often referred as inquiry, inductive, problem solving, decision making and invention. Contrary to direct instruction teaching strategies, indirect instruction teaching strategies put students as centers, even though both of them can complement each other. From this definition, it was found that every meeting in English online learning process at SMA N2 Lubuk Pakam were containing indirect learning strategy. Every learning activities were directed as the teacher provided the google classroom or Whatsapp as the learning environment, then The teachers shared the english materials in the form of text, either reading, questions or particular problems to solve. For example: following were some data showed how student learning indirectly:

Question to grade XI: R = researcher and $\mathrm{S}=$ student

R: saat belajar secara online, bagaimana guru merancang pembelajaran

"when You joining online English class, how did the teacher organize the learning?"

S: ketika kami tiba jam bahasa inggris, guru membri informasi dari grup Whatsapps, tentang apa yang harus kami lakukan, kadang diakirim bacaan untuk kami ringkas, kadang kami menjawab pertanyaan dari guru atau juga bentuk-bentuk situasi tertentu diminta membuatkan percakapan yang sesuai.

"on every English schedule, our English teachers provided information by Whatsapp or in google classroom. Then we were asked to do the task some time we got English text to read and made some translation or create our opinion to the story on ourselves words, sometime just answering questions or create conversation based on the setting given by the teacher.

From The above expression showed that teacher provided the indirect learning strategies. In which teacher provided English learning by sharing the learning prosses with particular situation then student did with their own management that considered as indirect instruction teaching strategy.

The Following expression still containing indirect learning strategy in her everyday online English learning.

Question to grade XII: $\mathrm{R}=$ researcher and $\mathrm{S}=$ student

R: saat belajar secara online, bagaimana guru merancang pembelajaran "when You joining online English class, how did the teacher organize the learning? Activities?"

S: biasanya kami diminta emembuka google classroom. Disana kami telah ada bahan untuk dikerjakan dalam bentuk bahasa inggris.

"we ofthen asked to open the google classrom, there, we found the English task to do. Of course in english".

From this second expression, showed that both grade $\mathrm{XI}$ and grade XII contain indirect instruction teaching in their english online learning.

\subsubsection{Direct Learning Strategy}

Hamruni (2009 explain direct instruction strategy is teaching directed by the teacher directly. It is usually teacher centered. This strategy usually practice for the low class, the teacher function the role model. In conducting online learning direct instruction strategy normally held in virtual meeting room when teacher and students can make two ways communication directly. In direct instruction strategy the teacher can evaluate the change of students behaviors as the result of learning process.

However, during observing and interviewing every participant related to direct instruction strategy, every participant said that direct instruction strategy was not applied during English online learning was delivered.

Question to inclusive student RM (Roma Manik)

$\mathrm{R}:$ sewaktu guru mengajar, apakah ada menggunakan instruksi-instruksi langsung?

"when teacher was teaching, did she use direct instruction?"

\section{Data $1 \mathrm{RM}$}

S: $\quad$ kalau guru menyampaikan pengajaran, paling sering hanya melakukan share materi pemblajaran lewat Whatsapp atau google classroom.

As far as I remember, the lesson was only shared by Whatsapp and google classroom.

From the statement above, it was found that there were some problems of applying direct online learning strategy: first, the problem of connection, even government had distributed internet data to help the online learning, not all student can receive the internet data.

Secondly, the students were not ready to apply virtual learning as the best way to practice direct instruction strategy. The other problems were some students were students perception toward learning from home, almost students still not comfortable when learning from home. 
This situation was in line with regular student answered below.

Question to regular student AB (Adam Bangun)

Data 2

R: setiap pertemuan, bagaimana cara guru menyampaikan bahan, apakah memberi arahan langsung atau cukup kirim bahan?

For every meeting, how did the teacher deliver the material, did she make direct instruction or just send the material?"

S: Sebagian besar pembelajaran kami dilakukan dengan guru mengirim materi ajar di Wag, berbentuk teks, atau voice atau vidio link, yang berisi bahan pelajaran lalu kami disituasikan mengerjakan tugas.

Most of our learning was done with the teacher sending teaching materials in Wag, in the form of text or voice note or video links, then we were situated to do assignments.

From above expression both regular and inclusive student stated that their English learning were established indirectly. This finding also support each other inclusive and regular students have the same strategy.

Next following question asked to English teacher in twelve IPS1, stated that during teaching online English learning, most interaction using WAG that sending learning material in the form of video and text.

Question to English teacher VW (Virgin Wati S.Pd) T = teacher

Data 3

$\mathrm{R}: \quad$ saat menyampaikan pelajaran, apakah ibu secara langsung memberi instruksi atau sekedar mengirim media-media lain?

when delivering English teaching, did you give direct instruction or just sending other media to deliver your instruction?

$\mathrm{T}$ : karena beberapa kendala pembelajaran sebagian besar saya sampaikan lewat WAG bentuk bacaan-bacaan atau contoh berupa youtube

for some reasons, most learning material were delivered by WAG they were available in the text and also youtube video.

From the above respons showed that theory about direct learning strategy by Hamruni was not used in English online learning to inclusive student at SMA N2 Lubuk Pakam both in grade XI and grade XII.

\subsection{Empirical / Experience Learning Strategy}

The Empirical / Experience learning strategy roles, students took place as the center. Self-reflection about their experience, is a planning formulation to achieve implementation based on context. The advantages of this strategy to increase student participation, as well as increase in student analytic aspects. While the disadvantages of this strategy were a high cost, and takes a long time.

Do to this type learning strategy the inclusive do English online learning by make some self creatifity such as, to provide their own mobile phone to help them to access online learning to be more effectively, e.g. All blind student who study at SMA N2 Lubuk pakam got difficulty to operate their mobile phone without screen reader help to change text in to voice. So they used screen reader to make easier to access their WAG, Google meet and also other services from internet. While for students who got problems in hearing and speaking, they use the other different application to change voice into text.

During observation made by online, each inclusive students join the learning media by applying their experience to reduce their limitation in receiving lesson. Another part of experience learning strategy that all student was showed during accessing online learning process was when every student asked to use social media E.g.: twitter and IG where student need to post their assignment's. So the students did not learn materials how to make posting on the both social media but with particular experience they can give result in their posting.

The following is the result of interview to inclusive student grade xii:

$\mathrm{R}=$ researcher and $\mathrm{S}=$ student

R: Apakah ada pengalaman blajar dari luar kelas yang dapat digunakan untuk mendukung peningkatan pembelajaran kamu secara online selama ini?

"did you have outside class experience that contribute to your online learning so far?"

S: Tentu banyak pak, terutama dimasa belajar online seperti sekarang ini.

Of course there were many, especially during the online learning period like now.

From the above expression, it is showed that in order to conect with english online lesson the student use his external experience to support his ability into access english subject. For example: to enable their mobile phone accessible the need to add particular aditional application to help them to operate it better.

The following expression came from grade XI showed that she also uses experiential learning strategy: 
Question to APS (Anna Putri Situmorang)

R: Apakah ada pengalaman dari luar kelas yang dapat berkontribusi untuk mendukung peningkatan pembelajaran kamu secara online selama ini?

Did you have another external experience that can support your online learning so far?

S: ya ada pak, saya kalau tampa modifikasi perangkat ponsel saya, tidak mampu memahami apa isi penjelasan yang dikirim dalam bentuk suara.

yes, there is sir, if I did not modify my cell phone device, I am unable to understand what the contents of the explanation are sent in voice form.

From the APS expresion above, it is showed that she as a deaf student use her external experience to modify her mobile phoone in the form of transvering voice in to text.

The following expression from English teacher SM (Sara Marpaung), $\mathrm{R}=$ researcher and $\mathrm{T}=$ teahcer)

Data 10

R: apakah dalam mengajar secara online, ibu melihat ada strategi pengalaman yang turut mendukung kelancaran pembelajaran bahasa inggrissecara online?

did you think that student external experiences give positive contribution to support their English online learning?

T: benar pak, kemarin ketika topik brochure, diakhir saya meminta semua siswa membuat brochure di media sosial "ig dan tw. Hasilnya lumayan kok.

That is right sir, on last meeting for the brochure topic, I ask all students to make brochure on social media "IG and tw.) The result was not bad.

From all expression above "grade XI, Grade XII and english teacher" showed that the english online learning contain empirical/experiential teaching strategy but most from the side of the students.

\subsection{Interactive Learning Strategy}

Interactive learning strategy emphasizes on discussion and share between the learners. It will encourage of learner to create new an idea or concept, reacting on experiences, approach and developing alternative mindset. The superiorities of interactive teaching strategy are students can improve their social skill and their ability, developing their rational argument.
The following question was addressed to inclusive student grade XI: $\mathrm{R}=$ researcher and $\mathrm{S}=$ student

R: Apakah pembelajaran selalu dikondisikan dalam bentuk penugasan atau diskusi?

Was learning majority organized in assignment activities or discussion?

S: sebagian besar pemblajaran dalam bentuk penugasan pak

we did meeting most to complete assignment activities sir

From above expression showed, even most of the learning activities held in the form of assignment, but it means that some other lesson also in the form of interactive learning strategy. For example: after the students submitting their assignment, then the teacher make farther elaboration either in the additional material or create discussion the next finding from above expression is that show how student did not use very effective interactive learning strategy. Because most of learning activities were containing assignment from the English teachers. So, in completing their works interactive learning was very limited could be delivered.

During learning activities teacher only gave short evaluation by using appreciation sentences, such as good, or it is still need improvement. Based on the observation when student open discussion seasons, only some students actively shared their ideas or questions toward the discussion itself. While according to another student in the different class, during following English online learning, interactive strategy was contained their learning activities.

Question to inclusive student grade XI APS (Anna Putri Situmorang)

Data 7

R: apakah pembelajaran dikondisikan selalu dalam bentuk penugasan atau diskusi?

was learning majority organized in assignment activities or discussion?

S: Di setiap topic, pertama ada penugasan Di GC kemudian minggu berikut ada penjelasan dan diskusi di google meet.

for each topic, first we have assignment in GC. In next meeting there was an explanation and discussion on Google meet.

From this second expression showed that the grade XI have better interactive teaching strategy than grade XII. This condition based on the observation, first the English teacher in grade XI is younger to English teacher in grade XII. So the English teacher in grade XI has more creative to deliver English lesson by providing English class not only in the form of assignment but always after sending 
material for Whatsapp, then create virtual meeting to apply interactive teaching strategy. Here teacher provide interactive learning by giving chance to ask and respond among students and also teacher as the moderators. So, from expression showed that interactive learning strategy was also used during English online learning delivered to inclusive student.

\section{CONCLUSION}

From the research that has been done about strategy of English online learning to Inclusive student at SMA N2 Lubuk Pakam in the academic year of 2020-2021, concluded that SMA N2 Lubuk Pakam has applied strategies to English online learning specifically, it is shown by the following percentage: direct instruction teaching strategy $0 \%$, indirect instruction teaching strategy ( $23.5 \%)$, empirical/experience learning strategy $(25 \%)$ interactive teaching strategy (19\%), and independent teaching strategy (32.5\%). It was based on Hamruny theory (2009) types of learning strategies.

\section{REFERENCES}

[1] Haver (2009), Haver, L. (2009). Components of a Successful ESL Classroom. Retrieved November 1st, 2011.

[2] Ellis, R. (1994). A Theory of Instructed Second Language Acquisition. In N. Ellis (Ed.), Implicit and Explicit Learning of Languages. Academic Press.www.sciepub.com.

[3] Haver (2009), 2. Haver, L. (2009). Components of a Successful ESL Classroom. Retrieved November 1 st, 2011.

[4] Oxford, R.L. (1989). Strategy Inventory for Language Learning. Alexanndria: V.A.: oxford Association.

[5] Oxford, R. L. (1990). Language learning strategies: What every teacher should know. New York: Newbury House/ Harper \& Row.

[6] Oxford, R. L. (2003). Language learning styles and strategies: An overview. Retrieved from - (1990). Language learning strategies: what Every Teacher should know. Newbury house.

[7] Rachmadtullah, et, al. 2020. Design of Instructional Strategy Model Based on the Brain's Natural Learning System (MS-sipao) in Inclusive Classrooms in Higher Education) Universal. Journal of Educational Research, Vol. 7(11), pp. 2352 2360

[8] Rubin, J. (1975). What the Good Learner Can Teach Us. Tesol Quarterly, 9: 41-51. 